\title{
Subsidence determined by InSAR - a review
}

\author{
Ana-Maria GLOD-LENDVAI \\ University of Bucharest, Faculty of Geography, \\ ana-maria.lendvai@drd.unibuc.ro
}

\begin{abstract}
Multi-temporal interferometry or InSAR allows monitoring of a deformation phenomenon at millimetre level, via the generation of mean deformation velocity maps and displacement time series from a data set of acquired SAR satellite images.

The advantages of satellite radar interferometry for displacement monitoring are demonstrated in cases of monitoring man-made structures (e.g. buildings, bridges, dams, subway lines, mines exploitation). This paper presents works in which subsidence phenomena were analyzed by InSAR technique.
\end{abstract}

Keywords: multi-temporal InSAR; land subsidence, underground structures, deformation

\section{INTRODUCTION}

Deformation of the ground in urban settings can occur through naturally induced factors, such as landslides or subsidence-uplift phenomena, and anthropogenic causes, as for the case of tunnelling excavations for urban subway lines or bridge and highways constructions. Ultimately, all these can result in serious damage to buildings. In the last years, InSAR (Interferometric synthetic aperture radar) technique has been developed for monitoring the ground movements; this technique represents an efficient instrument for remote sensing and measurements of surface displacements from urban settings with one centimetre to one millimetre accuracy (Bonano et al., 2014). The most known multi-temporal interferometry techniques are PS (Permanent Scatterer) and SBAS (Small BAseline Subset).

The use of PS technique in risk management analyzes depends very much on: (1) the number of data available and their temporal distribution; (2) PS density in points; (3) the motion of the targets with respect to the satellite LOS (Line of Sight); and (4) the presence of snow coverage (Ferretti et al., 2000).

For subsidence analysis, both temporal and spatial resolutions of the SAR satellite data are well suited for monitoring terrain settlement in urban areas. PS density in urban areas is usually greater than 100 PS/sq.m and thousands of square kilometres can be monitored monthly (Ferretti et al., 2000).

InSAR advanced techniques are a valuable tool in the landslide assessment because they allow remote investigation of the ground movement behaviour over long periods of time, benefiting of large sets of SAR images taken at different times that cover the same area in space. Among these techniques, the SBAS approach for surface deformation analysis can be applied to two spatial scales, i.e. regional and local scales.

\section{InSAR IDENTIFIED SUBSIDENCE AT INTERNATIONAL LEVEL IN THE SPECIALIZED LITERATURE}

The results obtained in the framework of the ESA Terrafirma project (www.terrafirma.eu.com) have confirmed the theoretical analysis on risk assessment. The subsidence in Rome, Italy was monitored within this project. Suburbs and even individual buildings affected by subsidence can be detected (Ferretti et al., 2000), as well as possible seasonal movements induced by the water table variations (Colesanti et al., 2003). 
Many examples of PS InSAR techniques applied to subsidence studies are available at TRE web site (www.treuropa.com). Companies from the oil and gas sectors are currently the major users of PS data. Precise surface deformation fields can be very valuable for reservoir exploitation (Vasco et al., 2008) and for identification of areas in the neighbourhood of the oil or gas wells, which can suffer damages.

Subsidence induced by mining activities can be also detected by means of PS InSAR (Colesanti et al., 2005).

In the city of Paris, 2 subsidence areas can be seen by interferometric techniques. Underground works were performed in both areas during 19951997 (Fruneau and Sarti, 2000).

The work of Bonano et al., (2014) presents an application of SBAS-InSAR technique to the urban area of Rome (Italy), aimed at investigating the displacements that, during the last two decades, have affected buildings within the downtown area. The analysis of the SBAS results is valuable to understand the spatial pattern and the magnitude of the settlements in comparison with a geological map.

In the work developed within the framework of the DORIS FP7-EU project, there are investigated the mass movements occurred in the Umbria region (central Italy) during the last 20 years, by exploiting ERS-1/2 and ENVISAT SAR images spanning the 1992-2010 time interval. This SBAS analysis allowed the detection of active landslides over all the study area, and further giving more insights on the spatial and temporal pattern of localized phenomena (Bonano et al., 2013)

Another applied example is the one from the city of Shanghai, located in the easternmost part of Yangtze Delta in China that is one of the most developed Chinese regions. The city experiences land subsidence. Excessive groundwater withdrawal is thought to be the primary cause of the land subsidence, but rapid urbanization and economic development, mass construction of skyscrapers, metro lines and highways are also contributing factors. The paper of Shaochun Dong et al. (2014) presents a spatial-temporal analysis of the land subsidence in Shanghai. The analysis was done on twenty L-band ALOS PALSAR images acquired during 2007-2010. They were performed with the help of the SBAS Interferometric technique. These images were used to produce a deformation rate map and to derive time series of ground deformation. The results show homogenous subsidence within the research area and exceptionally rapid subsidence around skyscrapers, along metro lines and highways. The authors consider that the subsidence monitoring is warranted because groundwater exploitation and rapid urbanization are responsible for much of the subsidence in the Shanghai region (Shaochun Dong et al., 2014).

Ground deformation affecting the Umbria region (central Italy) during 1992-2000 was investigated through InSAR Interferometry. For this purpose, the SBAS technique was adopted, which allows the studying of the temporal evolution of the detected deformation at two spatial scales: a low-resolution (regional) scale, and a full-resolution (local) scale. For this analysis, SAR data were acquired by the European Remote Sensing (ERS-1/2) satellites. The analysis of the spatial and the temporal characteristics of the ground displacement allowed the formulation of a hypothesis on the landslide geometry and deformation pattern (Fausto Guzzetti et al., 2009).

PS approach was used to investigate the iron mining site of Lorena (France). In this article, a special attention was given to the Roncourt case, where precursor signs of collapse affecting an area of $\sim 300 \times 300 \mathrm{~m}^{2}$ were identified (Colesanti et al., 2005).

The purpose of Biescas et al., (2007) paper is to describe two complementary approaches through InSAR technique. The first approach can measure slow land deformation (from a few millimeters up to some centimeters per year), and the second approach can measure fast land deformations (up to few meters per year). Emphasis is given to the description of the former approach, which requires multiple SAR images of the same phenomenon and an advanced analysis procedure. The effectiveness of both approaches is illustrated through two applications on mining areas of small spatial extent located in Spain. The white pixels indicate that no deformation estimates are available in those areas. 
In Herrera et al. (2007) paper, InSAR technique has been used to study the subsidence phenomena from the town of La Union (SE, Spain) for two time intervals, from January 1998 to December 2000, and from March 2003 to December 2004. The town of La Union (SE, Spain) is located within a metal mining area that has been exploited since Roman period. This historic exploitation has left behind a high concentration of abandoned underground mining galleries. InSAR technique has enabled the detection and monitoring of different deformation processes that affect several locations within the study area. By comparing these results with the underground mining galleries map, a clear relationship between their presence and the subsidence has been proved. Deformation values retrieved with InSAR between April 2003 and December 2004 have been compared with the topographical leveling measurements performed in the same period, providing an absolute average difference of $0.7 \mathrm{~cm}$ with a standard deviation of $0.5 \mathrm{~cm}$.

In Wegmuller et al., (2010) paper, it is shown how PS module permits the monitoring relatively fast (including rates up to $>50 \mathrm{~cm} /$ year) and nonuniform movements using deep-level mining. For this monitoring, TerraSAR X satellite observations have been used. In this paper, the used methodology, the obtained results and the validation of the results are described.

Raucoules et al. (2009) article presents the results within PSIC4 project. The project was based on the validation of the PS data with respect to leveling data on a subsiding mining area near Gardanne, in the South of France. The subsidence velocity intercomparison results obtained from PS data showed a standard deviation between 0.6 and $1.9 \mathrm{~mm} /$ year between the 8 teams. The velocity validation against rates measured on the ground showed a standard deviation between 5 and 7 mm/year. A comparison of the PS time series and leveling time series shows that if the displacement is larger than about $2 \mathrm{~cm}$ between two consecutive SAR-images, PS-InSAR starts to deviate seriously from the leveling time series. This point illustrates the importance of having ground information and a strong interaction with the end-user of the data, in order to understand properly the type and speed of the deformation that will be measured, and thus determine the applicability of the technique.

Herrera et al. (2008) analyze the subsidence in Murcia, Spain, by means of PS time series. Two PS methods (PS and SBAS) are compared in their study, and measurements are validated with the extensometers.

Ferretti (2007) paper analyzes the subsidence in the mining exploitation area from the East of France with InSAR data.

The Satellite Radar Interferometry reveals subsidence occurring in an area of about $2 \mathrm{~km}$ by 2 $\mathrm{km}$ inside the city of Naples, in the South of Italy. The observations show a maximum (vertical) displacement of about 5-6 cm between 1992 and 1996, while the deformation signal decreases between 1996 and 1998. The study demonstrates the high correlation between the observed deformation and the construction of a new underground railway line carried out between 1992 and 1995. The analysis from this study suggests a direct connection between the subsidence detected and the underground works evolution. This article demonstrates the measurement capacity by interferometric radar techniques of subsidence in urban and densely populated areas (Berardino et al., 2002).

Wegmüller et al. (2008), Wegmüller et al. (2010) and Colesanti et al. (2007) have described the subsidence determined by the existence of mining areas in their works.

The landslide activity in the area of Bolshoy Sochi (Big Sochi), situated at the Black Sea coast of the Great Caucasus has been studied using PSInSAR method. Comparative investigation of surface displacements obtained from three has been performed from January 2007 to September 2012. Analysis of the time series allowed to determine periods of activity and relative stability of landslides (Kiseleva et al., 2014).

The InSAR time series analysis coming from the ERS1 (1992-2000) and RADARSAT-1 (2003-2007) satellites highlighted a significant ground displacement in Naro region (Italy), due to the instability caused by the phenomenon occurred in February 2005. Through the InSAR analysis, it was 
established that the displacement rates were up to 6 $\mathrm{mm} / \mathrm{yr}^{-1}$ in 2003-2007, followed by a post-event stabilization. Through the integration of InSAR data and conventional field surveys (geological, geomorphologic), the causes of instability were attributed to tectonics (Cigna et al., 2011).

Three complementary GPS, LIDAR and InSAR methods have been used to study the surface deformation from Houston Metropolitan area. This study found a strong correlation between fluid withdrawals and subsidence because of a $4 \mathrm{~m} /$ year water level decline in the area of highest subsidence (Shuhab et al., 2014).

$\mathrm{Yu}$ and Wang (2015) paper studied the subsidence in the Gulf of Mexico region, formed in the Gulf of Mexico Coast and 20 US states of the Gulf appeared during 2005-2014 by using long term remarks from almost 450 GPS (CGPS) continuous stations. This region has been the heart of the US energy industry because of substantial oil and gas deposits along the coast. Furthermore, it is heavily populated and vulnerable to local ground deformation and relative sea-level rise.

Fuhrmann et al. (2012) present in their paper the measurement of 3D displacement by analyzing the GNSS measurements, leveling and InSAR data. In 2008, GNSS network was made from 80 permanent stations in Germany, France and Switzerland. The leveling measurements in the URG (Upper Rhine Graben) area were carried out by the ordinance survey of Germany, France and Switzerland, along leveling lines. These leveling lines were measured up to 5 times in the last 100 years. Therefore, at discrete benchmarks, a detailed assessment of surface displacements could be carried out. As leveling and GNSS are point-wise measurement techniques, the spatial resolution of estimated surface displacements is poor. Therefore, InSAR data is used to fill the gap in the future. A short outlook will point out the possibilities and limitations on the combination of GNSS, leveling and InSAR data for an accurate solution aiming for horizontal and vertical surface displacements in the URG.

Because the preparation of reliable landslide hazard and risk maps is crucial for hazard mitigation and risk management, Ping $\mathrm{Lu}$ et al.,
(2013) have introduced in their study a novel approach for updating landslide hazard and risk maps based on PS InSAR. The study was performed in the Arno River basin (central Italy), where most mass movements are slow-moving landslides, which are properly within the detection precision of PS point targets. In this study, the previous hazard and risk maps were updated using PS point targets processed for 4 years (2003-2006) of RADARSAT images.

InSAR time series are important to support civil protection activities in the framework of geological risk management and mitigation. The study areas are as follows: Agrigento and Naro (Italy). These areas are affected by ground instability respectively due to land sliding and tectonic forces. The study of past ground deformations provided valuable insights into the spatial and temporal patterns and behaviors of these phenomena, helping local civil protection authorities to focus the resources on the areas of maximum needs and to identify the most appropriate mitigation measures to reduce the impacts on elements at risk (Cigna et al., 2010).

In addition, InSAR data can provide effective information related to seismic risk management. InSAR data have demonstrated to be very valuable in the assessment and prevention phase, concerning scientific activities as hazard assessment, mitigation and preparedness. The main fields in which the InSAR-derived ground deformation is important are as follows: the parameterization of the seismic sources, the definition of the deformation rates related to the seismic cycle, the partitioning of strain among different faults, the improvement of tectonic models etc. In the warning and crisis phase, concerning all activities needed to promptly and effectively respond to the effect of an earthquake, InSAR data have also a good potential in activities such as earthquake source identification, urban damage assessment, and assessment of environmental effects of earthquakes. Salvi et al. (2012) have demonstrated the importance of InSAR data in the seismic risk management by using the Sentinel 1 satellite data.

The subsidence movements over the Shangyu District, on the south coast of the Hangzhou Bay, Zhejiang Province, China, have been monitored 
using PS InSAR data. Twenty-four scenes of COSMO-SkyMed images acquired between 2013 and 2015 have been used. The spatial pattern of the land subsidence obtained by the PS-InSAR and DS InSAR (Distributed Scatterers Interferometric SAR or interferometric distributed SAR) coincides with each other, but the density of the DSs is five times higher compared to the permanent scatterers (PSs). These data have been validated by precise leveling data, performed in the same period. The land subsidence in the Shangyu District is mainly distributed in the urban areas and industrial towns, with a maximum subsidence rate of $30.2 \mathrm{~mm} / \mathrm{year}$. The analysis of geological data, field investigation and historical reclamation data indicates that human activities are major causes of the detected land subsidence (Peng Han et al., 2017).

Poenaru et al. (2015) paper assesses lands by means of Synthetic Aperture Radar techniques. The subsidence from Ocnele Mari salt extraction area have been determined with RADARSAT2 dual polarized data acquired in the SOAR-16605 scientific proposal framework covering the July to December 2014 period.

Numerous studies on the subsidence monitoring and seismic activities have been performed in the salt extraction area (Zamfirescu et al., 2010; Trifu and Shumila, 2010; Poenaru et al., 2011).

As a result of the implementation of the strategic plan regarding safe exploitation and rehabilitation of the salt mining area adopted in 2007, degradation phenomena decreased in intensity, so that the study area became relatively stable in time $(-2,-4$ $\mathrm{mm} /$ year subsidence) (Poenaru et al., 2013).

The results of this study confirm that subsidence levelling measurement trends can be influenced by atmospheric conditions and soil moisture content (Poenaru et al., 2015).

Ground level subsidence analysis determined by InSAR data analysis have been also presented in the papers of Hsieh et al. (2011), Massonnet et al. (1993), Helleno et al. (2011), Hung et al. (2011), Vilhardo et al. (2009), Stramondo et al. (2007), Chatterjee et al. (2006), and Minxue et al. (2014).
Table 1. Classification of international-level subsidence displacements identified by InSAR applications, with references from the international literature

\begin{tabular}{|c|c|}
\hline Main classes & Data source and references \\
\hline Mining & $\begin{array}{l}\text { Colesanti et al., } 2005 \\
\text { Biescas et al., } 2007 \\
\text { Herrera et al., } 2007 \\
\text { Wegmuller et al., } 2010 \\
\text { Raucoules et al., } 2009 \\
\text { Ferretti, 2007 } \\
\text { Wegmüller et al., } 2008 \\
\text { Wegmüller et al., } 2010 \\
\text { Colesanti et al., } 2007 \\
\text { Poenaru et al. 2015 } \\
\text { Zamfirescu et al., } 2010 \\
\text { Trifu și Shumila, } 2010 \\
\text { Poenaru et al., 2011 } \\
\text { Poenaru et al., } 2013\end{array}$ \\
\hline $\begin{array}{l}\text { Groundwater } \\
\text { abstraction/recharge }\end{array}$ & $\begin{array}{l}\text { Colesanti et al., } 2003 \\
\text { Shaochun Dong et al., } 2014 \\
\text { Shuhab et al., } 2014\end{array}$ \\
\hline $\begin{array}{l}\text { Petrol and gas } \\
\text { abstraction }\end{array}$ & Yu şi Wang, 2015 \\
\hline Reservoir & Vasco et al., 2008 \\
\hline Flood risk & $\begin{array}{l}\text { Bonano et al., } 2013 \\
\text { Fausto Guzzetti et al., } 2009 \\
\text { Cigna et al., 2010) } \\
\text { Kiseleva et al., 2014 } \\
\text { Ping Lu et al., (2013) }\end{array}$ \\
\hline Urbanization & $\begin{array}{l}\text { Ferretti et al., } 2000 \\
\text { Bonano et al., } 2014 \\
\text { Shaochun Dong et al., } 2014 \\
\text { Berardino et al., } 2002 \\
\text { Peng Han et al., } 2017\end{array}$ \\
\hline \multirow[t]{2}{*}{$\begin{array}{l}\text { Subway } \\
\text { construction }\end{array}$} & Fruneau şi Sarti, 2000 \\
\hline & $\begin{array}{l}\text { Herrera et al., } 2008 \\
\text { Fuhrmann et al., } 2012 \\
\text { Poenaru et al., } 2015 \\
\text { Hsieh et al., } 2011 \\
\text { Massonnet et al., } 1993 \\
\text { Helleno et al., } 2011 \\
\text { Hung et al., 2011 } \\
\text { Vilhardo et al., } 2009 \\
\text { Stramondo et al., } 2007 \\
\text { Chatterjee et al., } 2006 \\
\text { Minxue et al., } 2014\end{array}$ \\
\hline Earthquake & $\begin{array}{l}\text { Salvi et al., } 2012 \\
\text { Zamfirescu et al., } 2010 \\
\text { Trifu și Shumila, } 2010 \\
\text { Poenaru et al., } 2011\end{array}$ \\
\hline
\end{tabular}




\section{InSAR IDENTIFIED SUBSIDENCE IN BUCHAREST CITY}

There are also several studies about the subsidence in Bucharest. In Dănişor, Fornaro and Dătcu (2016) paper, three tomographic algorithms are compared and applied to a dataset of 32 SAR images to generate the elevation map of dominant altitude from Bucharest. The results of those three spectral estimation methods (Beam-Forming, Least-Squares optimization and Capon filtering) have been evaluated by representing the elevation maps of the dominant scatterers, the immediate conclusion being that the main difference between these techniques is connected to the noise filtering capacity.

Pătraşcu, Popescu and Dătcu (2016) paper presents a comparative assessment of Synthetic Aperture Radar interferometric techniques (InSAR) that allow the detection of deformation models along the line-of-sight of the radar. Given the susceptibility of these methods to several limitations that act as noise effects in the interferograms, known as decorrelation phenomena, multi-temporal InSAR techniques have been issued for the exploiting of phase information acquired over long time intervals.

This article aims to perform a complete analysis of the deformations, which affect the area of Bucharest, using both PS InSAR and SBAS techniques. A comparison of the results has been performed. The proposed methodology has been applied on a set of 32 TerraSAR-X images, acquired over the South-Eastern area of Romania. The image stack covers a period of 16 months, from July 2011 to December 2012. A descending orbit characterizes all acquisitions (Pătraşcu, Popescu and Dătcu, 2016).

The quality of multi-temporal InSAR techniques is very difficult to assess without the existence of an a priori knowledge about the deformation in the area. This result shows a significant narrowing for equally sized sample sets. The estimated displacement rates for both methods are highly correlated, proving the similarity of displacement trends and values. Following the data analysis, a small deformation trend in the W-E direction was detected. A preliminary analysis of the average displacement rates [meters/year] for the TerraSAR-X image stack has allowed the identification of four regions of interest (Pătraşcu, Popescu and Dătcu, 2016).

Armaş et al. (2015) paper presents the use of three sets of single polarized synthetic aperture radar (SAR) satellite data and InSAR methodology to determine the spatial evolution and ground displacement trends of several industrial parks located in the metropolitan area of Bucharest. Consequently, 20 large industrial parks were selected for analysis and interpretation. InSAR analysis used SAR data acquired between 1992 and 2014 by ERS-1 /-2, ENVISAT and TerraSAR-X satellites. Ground movement patterns identified before and after 2000 were linked to groundwater table investigations based on 25 water wells located on or in the proximity of these areas. Estimated displacement rates over the last 24 years indicated that the surface of Bucharest is relatively stable. Although the estimated mean velocities are very small, the estimated patterns over the industrial areas were slightly distinct from their surroundings. Overall, the analysis shows that immediately following the communist era, an era characterized by intense exploitation of the groundwater resources, slow uplifting occurred over these industrial parks. This may be the result of closing the main industrial consumers, which decreased the water needs, followed by a come back to the zonal dynamic pattern. An exception was the continuous subsidence trend noted over the Berceni industrial area, one of the few industrial parks that not only continued to exist over time but also became more active in the last decade.

In Gheorghe and Armaş (2016) paper, two algorithms for InSAR data processing were compared. The obtained results emphasize the differences between the two algorithms. With an average velocity of $-2 \mathrm{~mm} /$ year up to $2 \mathrm{~mm}$ /year for PS and -1.6 to 1.6 for SBAS analysis, these values do not indicate an extreme case of subsidence in Bucharest.

During 2002-2009, lifting movements (a slight increase) were observed, while in 1992-2000 the movement was mainly subsidence. This could be caused by variations in groundwater level, but no 
testing measurements were available to verify this hypothesis (Vijdea et al., 2013).

Using InSAR PS data: 43 ERS-1/2 images acquired between 1992-1999, 34 Envisat ASAR scenarios between $2003-2009$ and 32 TRS-X Scripmap images between 2011 - 2012, a historical assessment of the city of Bucharest land was achieved and the subsidence areas were determined. Subsidence observed during 1992-1999 and 20032009 is explained by the accentuated compaction of the anthropogenic deposits on which the constructions were built. An analysis was also started on the area where a new metro line is currently located (Figure 1.10). Metro line monitoring activities began in March 2014: hydrological level (underground water table), geometric leveling, and inclinometric measurements (Poncos et al., 2014). A subsidence of over 10 $\mathrm{mm} /$ year was identified on a small surface (of almost $600 \mathrm{~m}$ ) in the Eastern side of Bucharest (Figure 1.11.), where a supermarket is built (Poncos et al., 2013).

The objective of Necşoiu, Armaş and Gheorghe (2013) research was to detect and monitor ground deformations in Bucharest, using InSAR data from TerraSAR-X (TSX) satellite.

Specifically, the short-time window of analysis (2011-2012) revealed ongoing processes along the rivers and on slopes at the micro relief level. Because of this short-term analysis, it was obtained a snapshot of the ground deformation during 20112012, possibly caused by various geomorphic and hydrologic processes (Necşoiu, Armaş and Gheorghe, 2013).

Point subsidence motions were also identified at the world's largest civilian building (i.e., Palace of the Parliament). In the case of the building, local compaction appears, based on a similar process as noted by Tosi et al., (2010) in areas located in the Northern Adriatic coast. Some historic fills and brick clay quarries also seem affected by downward motions. Subsidence motions have been noticed at the base of the river beds (Necşoiu, Armaş and Gheorghe, 2013).

Armaş et al. (2017) paper aimed to identify trends in Bucharest's ground displacement dynamics by analyzing three sets of synthetic aperture radar (SAR) over a period of 20 years:
ERS-1 / -2, ENVISAT and TerraSAR-X (TSX). InSAR estimates were compared to diachronic analyses based on detailed historical maps (i.e., Borroczyn map,1852; Szatmary map, 1864; Bucharest City Plan, 1911, 1921, 1940; topographical map, 1980) and orthophotomaps (2006, 2008 and 2010), ground measurements and traditional geological and traditional geomorphological investigations. The results suggest consistent displacement patterns over the city.

The subsidence areas from M5 metro line from Drumul Taberei neighborhood, city of Bucharest (Figure 1), have been determined at the CRMD (Center for Risk Studies, Space Modeling and Dynamics of Terrestrial and Coastal Systems). For this study, InSAR data were processed by PS technique from 24 TRS-X images, descendent, 27 TRS-X images, descendent, respectively, processed by SBAS technique for $2011-2014$ period.

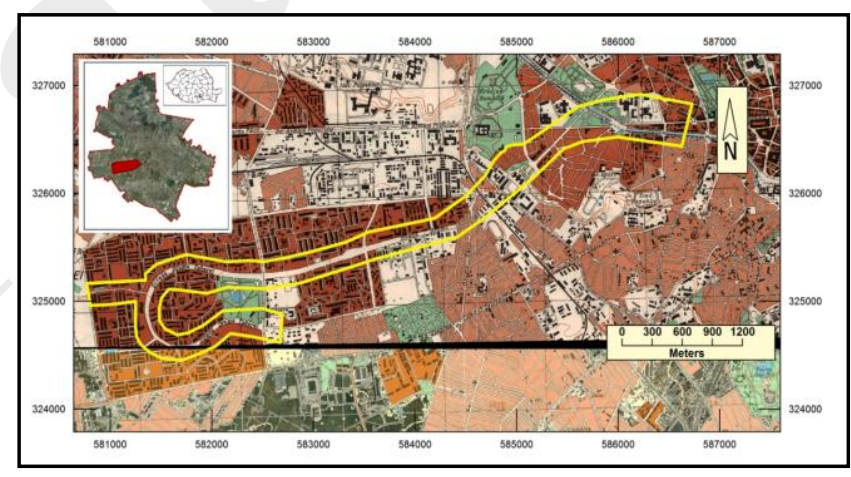

Figure 1. Study area

InSAR points obtained by PS, SBAS technique, respectively, inside a $200 \mathrm{~m}$ buffer were selected to determine subsidence motions. Almost 22000 points were obtained by PS technique in the $200 \mathrm{~m}$ buffer, which follows the M5 metro line on its both sides in the study area, and almost 16000 points, by SBAS technique. A statistical analysis was applied on these buffer points regarding the motion velocity during one year and the maximum subsidence areas were obtained. It should be noted that the subsidence areas coincide with the areas where works were performed during 2011-2014. Figure 2 shows the presence of 2 areas were subsidence motions occurs. 

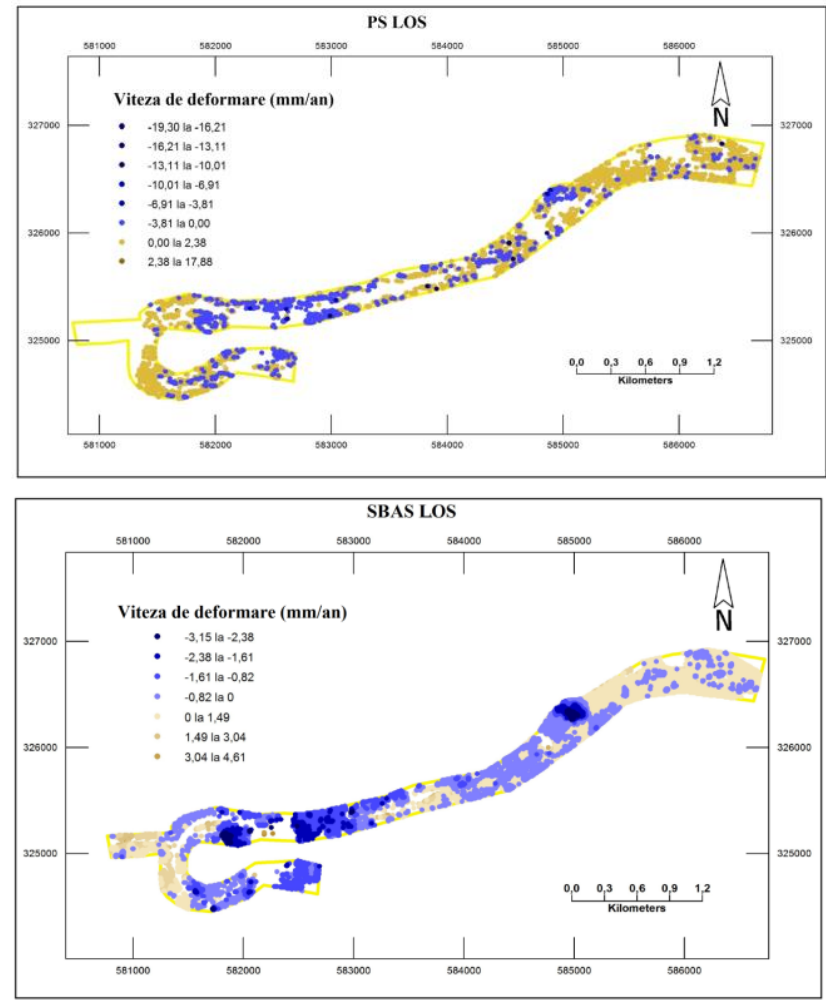

Figure 2. Deformation velocities in the M5 metro line area from Drumul Taberei

Therefore, the subsidence movement areas are:

Area 1 between Drumul Taberei (North), Târgu Neamț Street (East), Pașcani Alley (South) and Cetății Street (West).

Area 2 between Ana Davila Street (North), Gheorghe Marinescu Street (East), D. Bagdasar Street (South) and N. Păulescu Street (West).

Tabel 2. Classification of the city of Bucharest subsidence displacements identified by InSAR applications, with reference from the international literature

\begin{tabular}{|l|l|}
\hline Main classes & Data source and references \\
\hline $\begin{array}{l}\text { Groundwater } \\
\text { abstraction/recharge }\end{array}$ & $\begin{array}{l}\text { Vijdea et al., 2013 } \\
\text { Necşoiu, Armaş and Gheorghe, } \\
2013\end{array}$ \\
\hline Urbanization & $\begin{array}{l}\text { Dănişor, Fornaro and Dătcu, } \\
2016 \\
\text { Pătraşcu, Popescu and Dătcu, } \\
2016 \\
\text { Armaş et al., 2017 }\end{array}$ \\
\hline Industrial areas & Armaş et al., 2015 \\
\hline & $\begin{array}{l}\text { Gheorghe and Armaş, 2016 } \\
\text { Necşoiu, Armaş and Gheorghe, } \\
2013\end{array}$ \\
\hline $\begin{array}{l}\text { Subway } \\
\text { construction }\end{array}$ & $\begin{array}{l}\text { Poncos et al., 2013) } \\
\text { Poncos et al., 2014 }\end{array}$ \\
\hline
\end{tabular}

Copyright @ CRMD 2018

\section{CONCLUSIONS}

This article attempted to synthesize and demonstrate the utility of InSAR technique in studying the subsidence analysis. An important advantage of InSAR techniques is that they can be used for monitoring individual structures, but also to provide information at regional level and at larger scales.

All studies show the ability of InSAR to detect ground displacements that have occurred over hundreds or thousands of square kilometres and even at a national scale can be extremely useful in characterizing and addressing areas prone to subsidence caused by natural or anthropogenic causes.

InSAR limitations are related to temporal and geometric decors and atmospheric inhomogeneity. Although SAR sensors provide the advantage of SAR image acquisitions globally and at predefined time intervals, most of them provide relatively low resolution images.

\section{REFERENCES}

Armaş, I., Necşoiu, M., Aldea Mendes, D., Gheorghe, M., Gheorghe, D. (2015). Ground displacement trends in an urban environment using multi-temporal InSAR analysis and two decades of multi-sensor satellite_based SAR imagery, Conference Paper, DOI: $10.13140 /$ RG.2.1.1202.3847

Armaş, I., Aldea Mendes, D., Popa, R.-G., Gheorghe, M., Popovici, D. (2017). Long-term ground deformation patterns of Bucharest using multitemporal InSAR and multivariate dynamic analyses: a possible transpressional system?, Scientific Reports | 7:43762 | DOI: $10.1038 /$ srep43762

Berardino P., Fornaro G., Lanari R., Sansosti E. (2002). A new algorithm for surface deformation monitoring based on small baseline differential SAR interferograms. Ieee Transactions on Geoscience and Remote Sensing 40 (11):2375-2383

Biescas, E., Crosetto, M., Agudo, M., Monserrat, O., and Crippa, B. (2007). "Two Radar Interferometric Approaches to Monitor Slow and Fast Land Deformation." J. Surv. Eng., 10.1061/(ASCE)07339453(2007)133:2(66), 66-71.

Bonano, M., Calò, F., Manunta, M., Marsella, M., Scifoni, S., Sonnessa, A., Tagliafierro, V. (2014). Chapter Ground Settlement Assessment in Urban Areas Through SBAS-DInSAR Measurements: 
The Case Study of Roma (Italy), Engineering Geology for Society and Territory. 5: 985-988, 26.

Bonano, M., Calò, F., Manunta, M., Paglia, L., Zeni, G. (2013). Chapter Long-Term Analysis of Landslides Via SBAS-DInSAR Technique, Landslide Science and Practice, pp 141-146.

Chatterjee, R.S., Fruneau, B., Rudant, J.P., Roy, P.S., Frison, P.L., Lakhera, R.C., Dadhwal, V.K., Saha, R. Subsidence in Kolkata (Calutta) City, India, during the 1990s as observed from space by Differential Synthetic Aperture Radar Interferometry (D-InSAR) technique (2006). Remote Sens. Environ ;102:176-185.

Cigna F., Del Ventisette, C., Liguori, V. and Casagli, N. (2011). Advanced radar-interpretation of InSAR time series for mapping and characterization of geological processes, Nat. Hazards Earth Syst. Sci., 11, 865-881, www.nat-hazards-earth-syst-sci.net/11/865/2011/ doi:10.5194/nhess-11-865-2011.

Cigna F., Del Ventisette, C., Liguori, V., Casagli, N. (2010). Insar time-series analysis for management and mitigation of geological risk in urban area, Geoscience and Remote Sensing Symposium (IGARSS), 2010 IEEE International.

Colesanti, C., Ferretti, A., Novali, F., Prati, C., Rocca, F. (2003). SAR monitoring of progressive and seasonal ground deformation using the permanent scatterers technique. IEEE Trans Geosci Remote Sens, 41(7):1685-1701.

Colesanti C., Le Mouelicc, S., Bennanid, M., Raucoulesc, D., Carnecc, C. \& Ferretti, A. (2007). Detection of mining related ground instabilities using the Permanent Scatterers technique - a case study in the east of France, Journal of Surveying Engineering. 133(2): 201-207

Colesanti, C., Mouelic, S.L., Bennani, M., Raucoules, D., Carnec, C., Ferretti, A. (2005). Detection of mining related ground instabilities using the Permanent Scatterers technique - a case study in the east of France. Int. J. Remote Sens. 26 (1): 201-207.

Dănişor, C., Fornaro, G. and Dătcu, M. (2016). Inversion Algorithms and PS Detection in SAR Tomography, Case Study of Bucharest City, Telfor Journal, Vol. 8, No. 1.

Ferretti (2007). Detection of mining related ground instabilities using the Permanent Scatterers technique - a case study in the east of France, Journal of Surveying Engineering. 133(2): 201-207.

Ferretti, A., Prati, C., Rocca, F. (2000). Nonlinear subsidence rate estimation using permanent scatterers in differential SAR interferometry. IEEE Trans Geosci Remote Sens, 38(5):2202-2212.
Fruneau, B., Sarti, F. (2000). Detection of ground subsidence in the city of Paris using radar interferometry: isolation of deformation from atmospheric artifact using correlation, Geophysical Research Letters, 27(24): pages 3981-3984.

Fuhrmann, T., Knöpfler, A., Masson, F., Mayer, M., Ulrich, P., Westerhaus, M., Zippelt, K. and Heck, B. (2012). Horizontal and Vertical Surface Displacements in the Upper Rhine Graben Derived from GNSS and Precise Levelling Data, Geophysical Research Abstracts Vol. 14, EGU2012-10455, 2012 EGU General Assembly.

Gheorghe, M., Armaș, I. (2016). Comparison of MultiTemporal Differential Interferometry Techniques Applied to the Measurement of Bucharest City Subsidence, Procedia Environmental Sciences 32221 - 229, ScienceDirect, International Conference Environment at a Crossroads: SMART approaches for a sustainable future.

Guzzetti, F., Manunta, M., Ardizzone, F., Pepe, A., Cardinali, M., Zeni, G., Reichenbach P., Lanari R. (2009). Analysis of Ground Deformation Detected Using the SBAS-DInSAR Technique in Umbria, Central Italy, Pure and Applied Geophysics, Volume 166, Issue 8, pp 1425-1459, First online: 04 June 2009.

Helleno, S.I.N., Oliveira, L.G.S., Henriques, M.J., Falcao A.P., Lima J.N.P., Cooksley G., Ferretti A., Fonseca A.M., Lobo-Ferreira J.P., Fonseca J.F.B.D. (2011). Persistent Scatterers Interferometry detects and measures ground subsidence in Lisbon. Remote Sens. Environ; 115:2152-2167.

Herrera, G., Tomás, R., Lopez-Sanchez' J.M., Delgado, J., Mallorqui, J.J., Duque, S., Mulas, J. (2007). Advanced DInSAR analysis on mining areas: La Union case study (Murcia, SE Spain). Engineering Geology. 90(3-4): 148-159.

Herrera, G., Tomás, R., Lopez-Sanchez, J.M., Delgado, J., Mallorqui, J.J., Duque, S., Mulas, J., y De la VegaPanizo, R. (2008). Advanced Differential Interferometry analysis of ground deformation in La Unión (Murcia,Spain), Geo-Temas 10, (ISSN: 1567-5172).

Hsieh, C.S., Shih, T.Y., Hu, J.C., Tung, H., Huang, M.H. (2011). Angelier J. Using differential SAR interferometry to map land subsidence: A case study in Pingtung Plain of SW Taiwan. Nat. Hazards. 58: 1311-1332.

Hung, W.C., Hwang, C., Chen, Y.A., Chang, C.P., Yen, J.Y, Hooper, A., Yang, C.Y. (2011). Surface deformation from persistent scatterers SAR interferometry and fusion with leveling data: A case study over the Choushui River Alluvial Fan, Taiwan. Remote Sens. Environ. 115:957-967. 
Massonnet, D., Rossi, M., Carmona, C., Adragna, F., Peltzer, G., Feigi, K., Rabaute, T. (1993). The displacement field of the Landers earthquake mapped by radar interferometry.Nature; 364:138-142.

Minxue, Z., Fukuyama, K. and Sanga-Ngoie, K. (2014). Application of InSAR and GIS Techniques to Ground Subsidence Assessment in the Nobi Plain, Central Japan, Sensors (Basel); 14(1): 492-509.

Necşoiu, M., Armaş, I. and Gheorghe, D. (2013). Detecting deformation in Bucharest; Romania, using highresolution multitemporal InSAR and TerraSAR-X data, 5th TerraSAR-X Science Team Meeting DLR, Oberpfaffenhofen, Germany.

Pătrascu, C., Popescu, A.A., Dătcu M. (2016). Comparative assessment of multi_temporal InSAR techniques for generation of displacement maps: a case study for Bucharest area, U.P.B. Sci. Bull., Series C, Vol. 78, Iss. 2, ISSN 2286-3540.

Peng, H., Yang, X., Bai, L., Sun, Q. (2017). The monitoring and analysis of the coastal lowland subsidence in the southern Hangzhou Bay with an advanced time-series InSAR method, Volume 36, Issue 7, pp 110-118.

Ping, L., Catani, F., Tofani, V., Casagli, N. (2013). Quantitative hazard and risk assessment for slowmoving landslides from Persistent Scatterer Interferometry, Landslides DOI 10.1007/s10346-0130432-2, Springer-Verlag Berlin Heidelberg.

Poenaru, V.D., Badea, A., Savin, E., Teleagă, D. and Poncos, V (2011), Land degradation monitoring in the Ocnele Mari salt mining area using satellite imagery, Proceeding SPIE, vol. 8181 818110U-1.

Poenaru, V., Dana, I., Teleagă, D., Poncos, V. (2013), Land deformation monitoring in the Ocnele Mari salt mining area using VHR TSX data, TerraSAR-X Science Team Meeting, DLR Oberpfaffenhofen, Germany.

Poenaru V., Badea A., Cîmpeanu, S.M., Negula, I.D. (2015). Synthetic aperture radar for assessing land degradation in a salt mining area - Ocnele Mari case.study, Rev. Roum. Geogr./Rom. Journ. Geogr. 59(2): 117-127, Bucureşti.

Poncos, V., Teleaga, D., Pătrascu, C., Dătcu, M. (2013). Monitoring Urban Subsidence in Bucharest City with TerraSAR-X.

Raucoules, D., B. Bourgine, M. de Michele, G. Le Cozannet, L., Closset, C., Bremmer, H., Veldkamp, D., Tragheim, L., Bateson, M., Crosetto, M., Agudo, M. Engdahl (2009). Validation and intercomparison of Persistent Scatterers Interferometry: PSIC4 project results. Journal of Applied Geophysics. 68(3): 335-347 (earth.esa.int/ psic4).

Salvi, S., Sarti, F., Mouratidis, A., Coletta, A., Zoffoli, S. (2012). InSAR monitoring for seismic risk management: the Sentinel 1 contribution, EGU General Assembly, Vienna, Austria, p. 11278.

Shaochun D., Samsonov S., Yin H., Ye S., Cao Y. (2014). Time-series analysis of subsidence associated with rapid urbanization in Shanghai, China measured with SBAS InSAR method, Environmental Earth Sciences, 72(3): 677-691, First online: 10 December 2013.

Shuhab, D. K., Huang, Z., Karacay, A. (2014). Study of ground subsidence in northwest Harris county using GPS, LiDAR, and InSAR techniques, Nat Hazards 73:1143-1173, DOI 10.1007/s11069-014-1067-x.

Stramondo, S., Saroli, M., Tolomei, C., Moro, M., Doumaz, F., Pesci, A., Loddo, F., Baldi, P., Boschi, E (2007). Surface movements in Bologna (Po PlainItaly) detected by multitemporal D InSAR. Remote Sens. Environ. 110: 304-316.

Trifu, C.I. and Shumila, V. (2010). Microseismic Monitoring of a Controlled Collapse in Field II at Ocnele Mari, Romania, Pure Appl. Geophys. 167: 27-42.

Tosi, L., Teatini, P., Strozzi, T., Carbognin, L., Brancolini, G., and Rizzetto, F. (2010). Ground surface dynamics in the northern Adriatic coastland over the last two decades. Rendiconti Lincei, 21: 115-129.

Vasco, D.W., Ferretti, A., Novali, F. (2008). Reservoir monitoring and characterization using satellite geodetic data: interferometric synthetic aperture radar observations from the Krechba field. Algeria Geophysics, 73 (6), pp. WA113-WA122.

Vijdea, A., Bindea, G. (2013). "Geohazard description for Bucharest", PanGeo D7.1.33 research report.

Wegmüller, U., Walter, D., Spreckels, V., Werner, C. (2008). Evaluation of TerraSAR-X DINSAR and IPTA for ground motion monitoring. Proc. of The 3rd TerraSAR-X Science Team Meeting, 25-26 Nov 2008, DLR, Oberpfaffenhofen, Germany.

Wegmüller, U., Walter, D., Spreckels, V., Werner, C. (2010). Nonuniform ground motion monitoring with TerraSAR-X persistent scatterer interferometry. IEEE Trans. Geosci. Remote Sens. 48: 895-904. doi: 10.1109/TGRS.2009.203792.

Yu, J., Wang, G. (2015). GPS derived ground motions (2005-2014) within the Gulf of Mexico region referred to a stable Gulf of Mexico reference frame, Nat. Hazards Earth Syst. Sci. Discuss., 3: 6651-6688, doi:10.5194/nhessd-3-6651-2015.

Zamfirescu, F., Giurgiu, N., Popescu, V. and Copăescu, S. (2010). Present - day situation of Ocnele Mari wellfields following 48 years of the salt exploitation by dissolution already, close to be and approaching solved problems - a technical solution for the collapse fragmentation of the field 2 cavern Ocnele Mari, Romania, Technical report. 